\title{
2. GEOLOGIC AND TECTONIC SETTING OF THE MARK AREA ${ }^{1}$
}

\author{
R. S. Detrick, P. J. Fox, N. Schulz, and R. Pockalny, Graduate School of Oceanography, University of Rhode \\ Island, Kingston, Rhode Island 02881 \\ L. Kong, Woods Hole Oceanographic Institution, Woods Hole, Massachusetts 02543; and Department of Earth, \\ Atmospheric and Planetary Sciences, Massachusetts Institute of Technology, Cambridge, Massachusetts 02139 \\ L. Mayer, Department of Oceanography, Dalhousie University, Halifax, Nova Scotia, Canada \\ and \\ W.B.F. Ryan, Lamont-Doherty Geological Observatory, Palisades, New York 10964
}

\section{INTRODUCTION}

The Mid-Atlantic Ridge (MAR) rift valley near $23^{\circ} \mathrm{N}$ and the adjacent Kane Fracture Zone, known collectively as the MARK area (Fig. 1), have been the site of numerous marine geological and geophysical investigations dating back to the late 1960's. These studies have included conventional wide-beam bathymetric surveying (Purdy et al., 1979; Cormier et al., 1984), dredging (Miyashiro et al., 1969; 1970; van Andel et al., 1969; Fox, 1972; Bryan et al., 1981), seismic-refraction experiments (Detrick and Purdy, 1980; Cormier et al., 1984; Purdy and Detrick, 1986), gravity studies (Louden and Forsyth, 1982), and detailed ALVIN and ANGUS investigations (Karson and Dick, 1983; Karson et al., 1986; in press). These studies established the MARK area as one of the best known parts of the Mid-Atlantic Ridge and led to its selection as the site of a major crustal-drilling effort on ODP Legs 106 and 109.

In preparation for the drilling in this area, a joint United States/Canadian research team, including investigators from the University of Rhode Island, Lamont-Doherty Geological Observatory, Dalhousie University, and Woods Hole Oceanographic Institution, were funded to carry out a predrilling site survey, using two state-of-the-art seafloor mapping tools: Sea Beam, a high-resolution multibeam echo-sounding system, and SeaMARC I, a mid-range, deep-towed side-scan sonar (Detrick et al., 1985). These surveys, a subsequent ALVIN/ANGUS investigation of the MARK area (Karson et al., 1986; in press), and a recently published seismic-refraction line along the rift valley (Purdy and Detrick, 1986) provide the basic geological framework within which the drilling results from ODP Legs 106 and 109 are interpreted. In this chapter, we briefly summarize the most important results to emerge from these recent studies.

\section{MORPHOLOGY OF THE RIFT VALLEY}

Although conventional wide-beam bathymetric maps of the MARK area (Purdy et al., 1979; Cormier et al., 1984) suggested the presence of a relatively simple, linear rift valley having no major transform offsets for a distance of more than $100 \mathrm{~km}$ south of the Kane Transform, the high-resolution Sea Beam bathymetry maps acquired during the site survey reveal a rift valley that is surprisingly complex at all scales, both along- and acrossstrike (Detrick et al., 1984). A 100-m-contour bathymetry map of the MARK area is shown in Figure 2. Nearly complete Sea Beam coverage of the rift valley is available from the Kane transform south to about $22^{\circ} 30^{\prime} \mathrm{N}$. The rift valley, which trends $010^{\circ}$, is typically bordered on both the east and west by rift mountains

\footnotetext{
${ }^{1}$ Shipboard Scientific Party, 1988. Proc. ODP, Init. Repts. (Pt. A), 106/109: College Station, Texas (Ocean Drilling Program).
}

that rise up to $2000 \mathrm{~m}$ above the rift valley floor, although rift mountains are largely absent between $23^{\circ} 10^{\prime} \mathrm{N}$ and $23^{\circ} 20^{\prime} \mathrm{N}$ on the west and near $23^{\circ} 00^{\prime} \mathrm{N}$ on the east. The rift mountains rise in a steplike manner above the valley floor; flat areas of variable width link narrow intervals of steep relief.

Two opposing north-northeast-trending scarps, typically about $500 \mathrm{~m}$ high, define the limits of a rift valley floor that ranges in width from about 10 to $17 \mathrm{~km}$. The floor of the rift valley is shallowest (slightly $<3200 \mathrm{~m}$ ) and narrowest $(10 \mathrm{~km})$ about 70 $\mathrm{km}$ south of the Kane transform (referred to as the "saddle" area). The rift valley gradually deepens and widens northward toward the Kane transform, plunging to depths of 5000-6000 m in the ridge/transform intersection area (Fig. 3). The northern part of the rift valley immediately south of the Kane transform is dominated by a long-median ridge, which systematically narrows and deepens as it approaches the ridge/transform intersection. The along-strike continuity of this feature, the abundant exposure of fresh, sediment-free basalts, and the discovery of hydrothermal activity on this ridge about $25 \mathrm{~km}$ south of the ridge/transform intersection (Kong et al., 1985; Detrick et al., 1986) all suggest that this feature is the most likely location of the neovolcanic zone in the northern part of the rift valley. To the south, this ridge deepens and disappears in a zone of confused topography near $23^{\circ} 10^{\prime} \mathrm{N}$. To the north, the median valley ridge can be traced into and across the ridge/transform intersection area as a series of small, 20-100-m-high, conically shaped peaks, inferred to be volcanic edifices (Karson and Dick, 1983; Pockalny et al., in press).

A large, closed-contour depression, or nodal basin, dominates the topography of the eastern ridge/transform intersection (Fig. 2). More circular in shape than many nodal basins associated with Atlantic transforms (Sleep and Biehler, 1970; Fox and Gallo, in press), it is about $10 \mathrm{~km}$ in diameter at the $5000-\mathrm{m}$ isobath. The center of the basin has water depths $>6100 \mathrm{~m}$, one of the deepest points in the North Atlantic.

Pockalny et al. (in press) described the marked structural asymmetry on either side of the nodal basin. The eastern rift valley wall is relatively deep $(3500-4000 \mathrm{~m})$ and is characterized by two broad, cuspate ridges that have the same shape as the neovolcanic zone (Fig. 2). These ridges plunge and taper as the fracture zone is approached, mimicking the along-strike morphology of the median ridge. The similarity in the shape of these ridges with the present neovolcanic zone strongly suggests that they are volcanic constructional features that formed within the rift valley and have been transported, without significant dismemberment by faulting, laterally to their present position (Pockalny et al., in press). In contrast, the western rift valley wall at the ridge/transform intersection is marked by a shallow, rectangular shaped ridge that stands almost $5000 \mathrm{~m}$ above the adjacent nodal basin (Fig. 2). This block, sometimes re- 


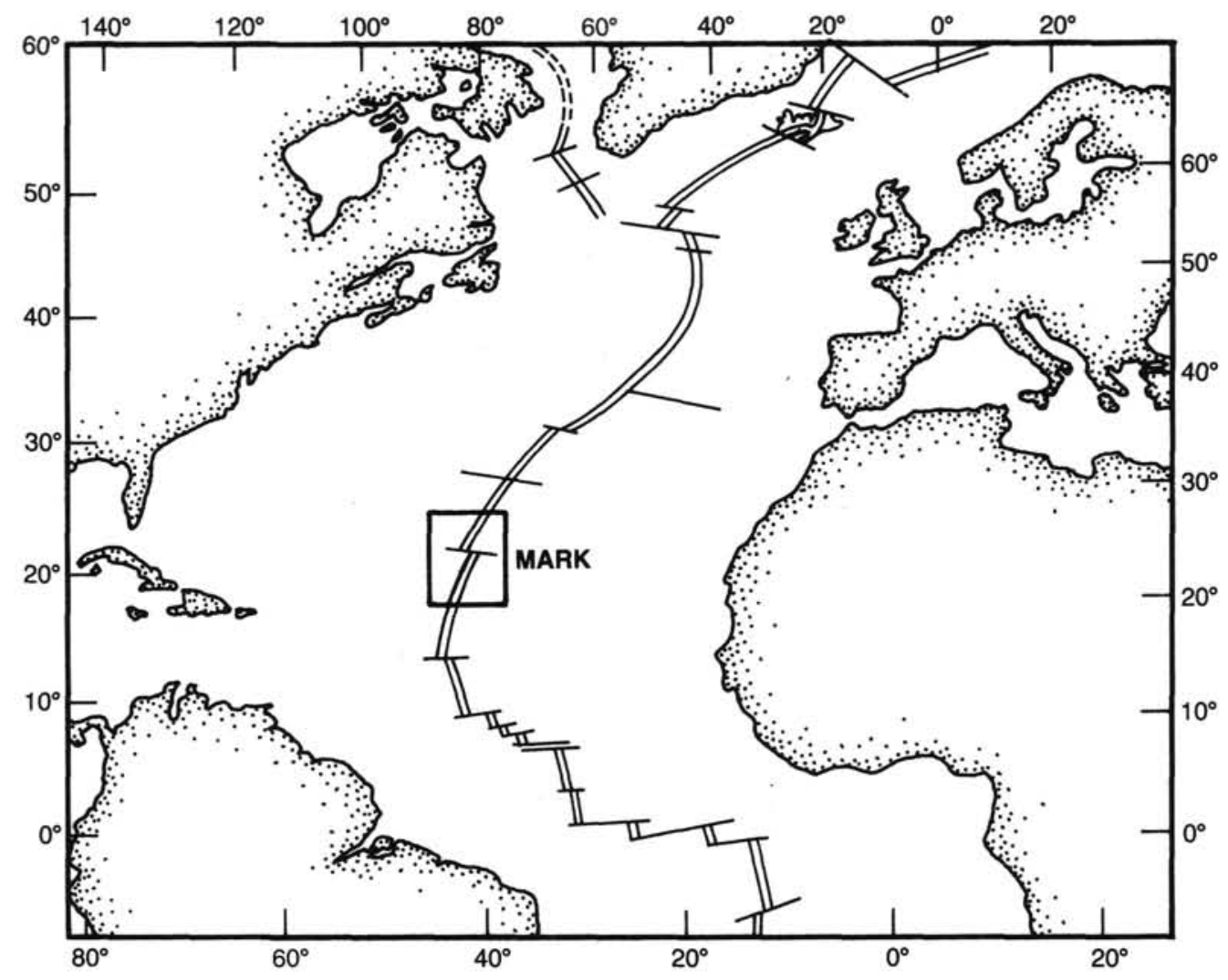

Figure 1. Generalized tectonic map of the North Atlantic showing the location of the MARK area, a well-studied part of the Mid-Atlantic Ridge near the Kane Fracture Zone.

ferred to as an "inside-corner high," is characterized by secondorder, ridge-axis parallel terrain elements that pinch out to the north along the exceptionally steep $\left(\sim 20^{\circ}\right.$ regional slope), 3000-m-high, transform-parallel scarp that defines the southern wall of the Kane transform valley. In-situ investigations of the escarpments on the east-facing rift valley wall using ALVIN (Karson and Dick, 1983; Karson et al., 1986; in press) reveal the routine exposure of variably deformed and metamorphosed gabbroic rocks up the face of this steep slope and minor occurrences of basalts and diabases.

\section{TECTONICS OF THE RIFT VALLEY FLOOR}

The floor of the inner rift valley in the MARK area between $23^{\circ} 35^{\prime} \mathrm{N}$ and $22^{\circ} 40^{\prime} \mathrm{N}$ was extensively mapped during the SeaMARC I part of the site survey (Mayer et al., 1985). A tectonic map of the rift valley based on a preliminary interpretation of the SeaMARC images is shown in Figure 4.

The floor of the rift valley is characterized by numerous small volcanoes, many having collapsed summit craters, and several elongate basins and ridges, which integrate spatially to create a structural grain that strikes $015^{\circ}$, slightly oblique to the regional trend of the rift valley. Two en-echelon rifts are apparent, one associated with the median ridge identified on the Sea Beam map in the northern part of the rift valley and a second composed of a broad band of small axial volcanoes, each typically $50-100 \mathrm{~m}$ high, that extend from $22^{\circ} 45^{\prime} \mathrm{N}$, northward across the saddle area to the eastern wall of the rift valley near $23^{\circ} 15^{\prime} \mathrm{N}$ (Fig. 4). These volcanoes are cut by numerous valley-parallel faults and fissures and surrounded and partially buried by more recent flows. The extensive fissuring and nearly continuous sediment cover on areas of low relief in the saddle area suggest that a significant time has elapsed since the most recent episode of volcanic activity along this part of the rift valley. This observation is somewhat unexpected because the Francheteau and Ballard (1983) model predicts that the along-axis topographic high should be the locus of the most recent magmatic and hydrothermal activity. Instead, the SeaMARC I results suggest the most recent volcanic activity in the MARK area is associated with the median ridge found in the northern part of the rift valley, near the Kane transform.

This interpretation is supported by a recent ALVIN and ANGUS investigation of the MARK area (Karson et al., 1986; in press). The submersible observations confirm the presence of a magmatically active spreading cell about $50 \mathrm{~km}$ in length that extends south from the Kane transform and an older, inactive cell in the southern part of the rift valley, south of $23^{\circ} 05^{\prime} \mathrm{N}$. An anomalous region between $23^{\circ} 05^{\prime} \mathrm{N}$ and $23^{\circ} 15^{\prime} \mathrm{N}$ separates these two areas and is characterized by intensely fissured, rough rift valley topography, poorly developed rift valley walls, and the exposure of serpentinized peridotites along the western edge of the rift valley. The major along-axis changes in morphology, magnetic activity, and tectonic extension documented in this study and apparent in the Sea Beam and SeaMARC I data shown in Figures 2 and 4 suggest that accretionary processes at the MAR are much more complex than earlier studies had suggested (Karson et al., in press).

\section{CRUSTAL STRUCTURE OF THE RIFT VALLEY}

The crustal structure of the rift valley within the MARK area was determined from a single $130-\mathrm{km}$-long explosive seismic-refraction line shot along the rift valley from just south of the ridge/transform intersection through the saddle area to about $22^{\circ} 30^{\prime} \mathrm{N}$ (Purdy and Detrick, 1986). An illustration of the results of this experiment is shown in Figure 5. 


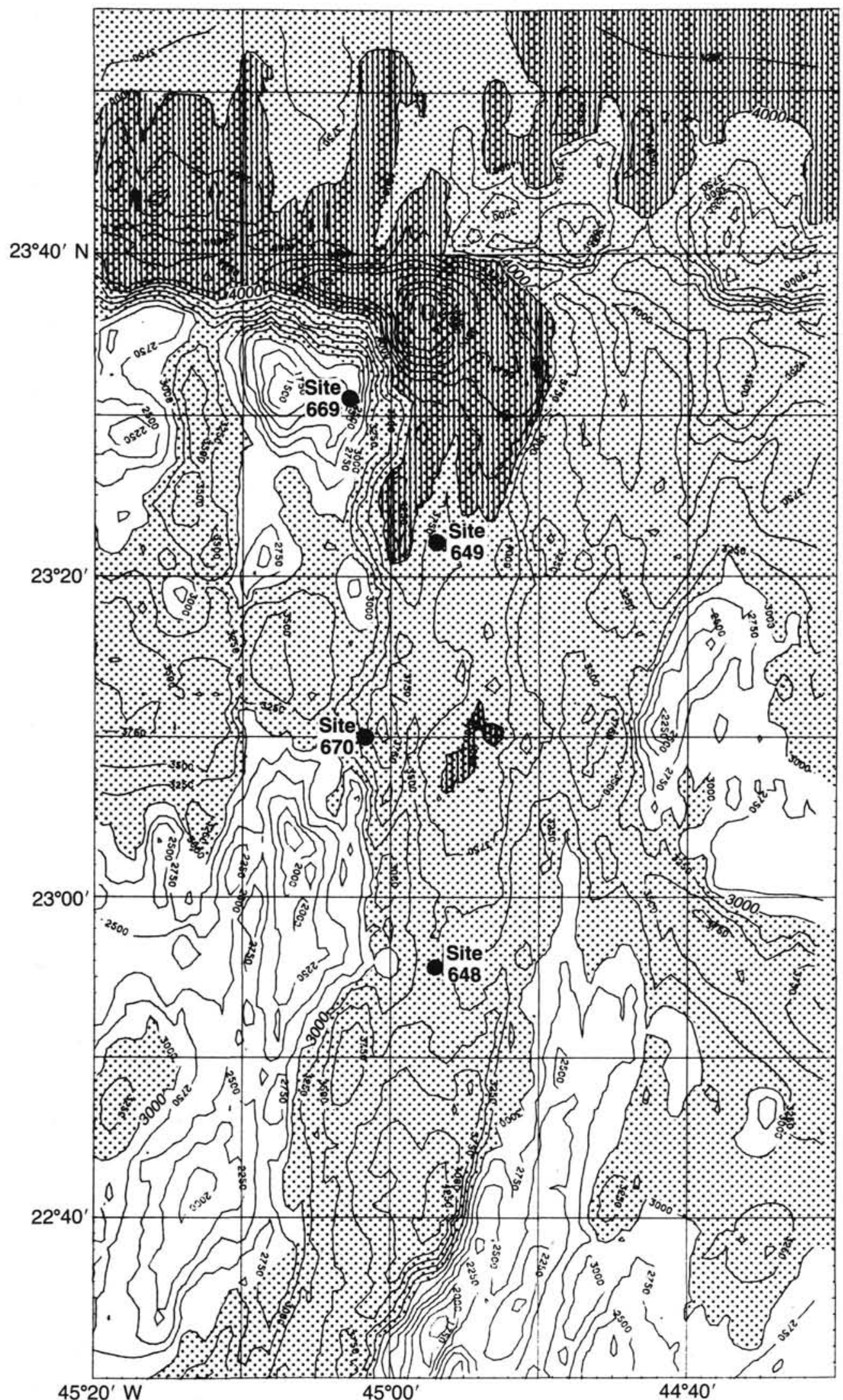

Figure 2. Sea Beam bathymetric map of the MARK area (from Detrick et al., 1984). Contour interval $250 \mathrm{~m}$. Depths shallower than $3000 \mathrm{~m}$ are unshaded, depths between 3000 and $4000 \mathrm{~m}$ are indicated by a light stipple pattern and depths greater than $4000 \mathrm{~m}$ are darkly shaded. Locations of sites occupied on ODP Leg 106 and 109 are shown for reference. 


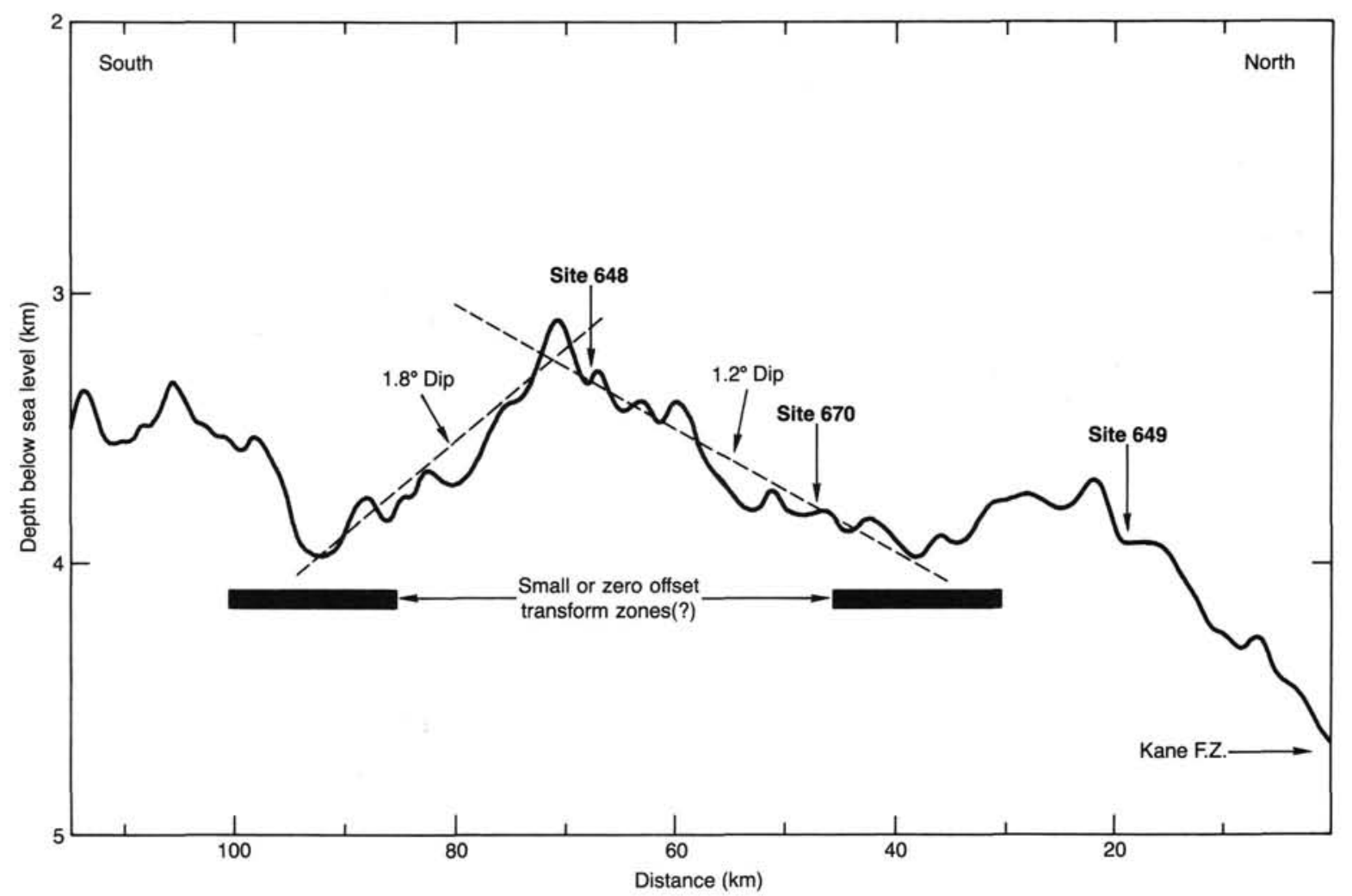

Figure 3. Bathymetry profile along the axis of the Mid-Atlantic Ridge rift valley, illustrating the regional variation in the depth of the rift valley floor toward the Kane transform. The approximate location of Sites 648, 649, and 670 are shown for reference (from Purdy and Detrick, 1986).

A major structural discontinuity occurs at $23^{\circ} 15^{\prime} \mathrm{N}$ that is coincident with the anomalous geologic and bathymetric observations previously discussed. North of this boundary, which represents a major propagation block for seismic energy, the crust is $4-5 \mathrm{~km}$ thick and lacks the distinct amplitude patterns that characterize refraction data from normal oceanic crust. South of $23^{\circ} 15^{\prime} \mathrm{N}, 6-7-\mathrm{km}$-thick, mature oceanic crust appears to be present with a well-defined Moho transition zone and $\sim 8 \mathrm{~km} / \mathrm{s}$ upper-mantle velocities. Purdy and Detrick (1986) proposed that this seismic discontinuity may represent a "zero-offset" transform (Schouten and White, 1980), or a boundary between two distinct spreading-center cells in the rift valley.

No evidence exists in the seismic data for a magma chamber in the crust or upper-mantle in the MARK area. However, since the refraction line passes about $6-8 \mathrm{~km}$ east of the median ridge that marks the neovolcanic zone in the northern part of the rift valley, the existence of a crustal magma chamber beneath this feature cannot be ruled out. A zone of low crustal velocities was inferred in the lower crust beneath the saddle area (Fig. 5). Purdy and Detrick (1986) interpreted this feature to be the remnants of the most recent phase of magmatic activity, which has temporarily left behind a region of elevated temperatures and pervasive cracking in the lower crust. However, because this part of the rift valley does not appear to have undergone recent volcanic activity, the explanation of this feature remains unclear.

\section{SPREADING HISTORY}

Additional constraints on the tectonic evolution of the MARK area over the past 3 million years were obtained from an analysis of magnetic data obtained during the Sea Beam part of the predrilling site survey (Schultz et al., 1986). Magnetic-anomaly profiles across the rift valley are shown in Figure 6, with a calculated profile from a simple block model. Anomaly identifica- tions based on this model are summarized in Figure 7. The central magnetic anomaly is not a simple linear feature centered over the rift valley but is segmented into a series of elongate highs aligned along the ridge axis. In the southern part of the rift valley, the central anomaly is characterized by a single peak located over the eastern edge of the rift valley. In the saddle area, the central anomaly is associated with a distinct double peak, whereas further north it again appears as a single high centered over the median valley ridge, except near $23^{\circ} 30^{\prime} \mathrm{N}$, where the central anomaly appears to have shifted eastward out of the rift valley.

The spreading in this area has been asymmetric $(1.41 \mathrm{~cm}$ $\mathrm{yr}^{-1}$ to the west and $1.13 \mathrm{~cm} \mathrm{yr}^{-1}$ to the east) over the past 3-4 m.y. This asymmetric spreading has been accomplished by a series of small $(\sim 10 \mathrm{~km})$, eastward ridge jumps, which have left duplicated anomalies on the western ridge flank (Fig. 7). However, the entire MARK rift valley has not acted as a single tectonic unit. The ridge jumps occurred just after the Jaramillo Event $(<0.7$ m.y. ago) in the northern and southern parts of the MARK area and after anomaly 2 formed $(\sim 1.5 \mathrm{~m}$.y. ago $)$ in the central part of the area. These results suggest that some of the ridge segments identified within the rift valley today have operated as discrete and independent units for a period of at least a few million years.

A small transform was located about $50 \mathrm{~km}$ south of the Kane Transform at anomaly $2^{\prime}$ time $(\sim 2.5$ m.y. ago $)$. This leftlateral transform existed until an eastward shift of the ridge segment north of the transform eliminated this offset $<0.7$ m.y. ago (Fig. 7). However, the existence of this small fracture zone may be reflected in the disturbed topography in the western rift mountains present between $23^{\circ} 10^{\prime} \mathrm{N}$ and $23^{\circ} 15^{\prime} \mathrm{N}$ and the absence of a well-developed rift valley (see Fig. 2). The low amplitude of the central magnetic anomaly at this latitude (profile 


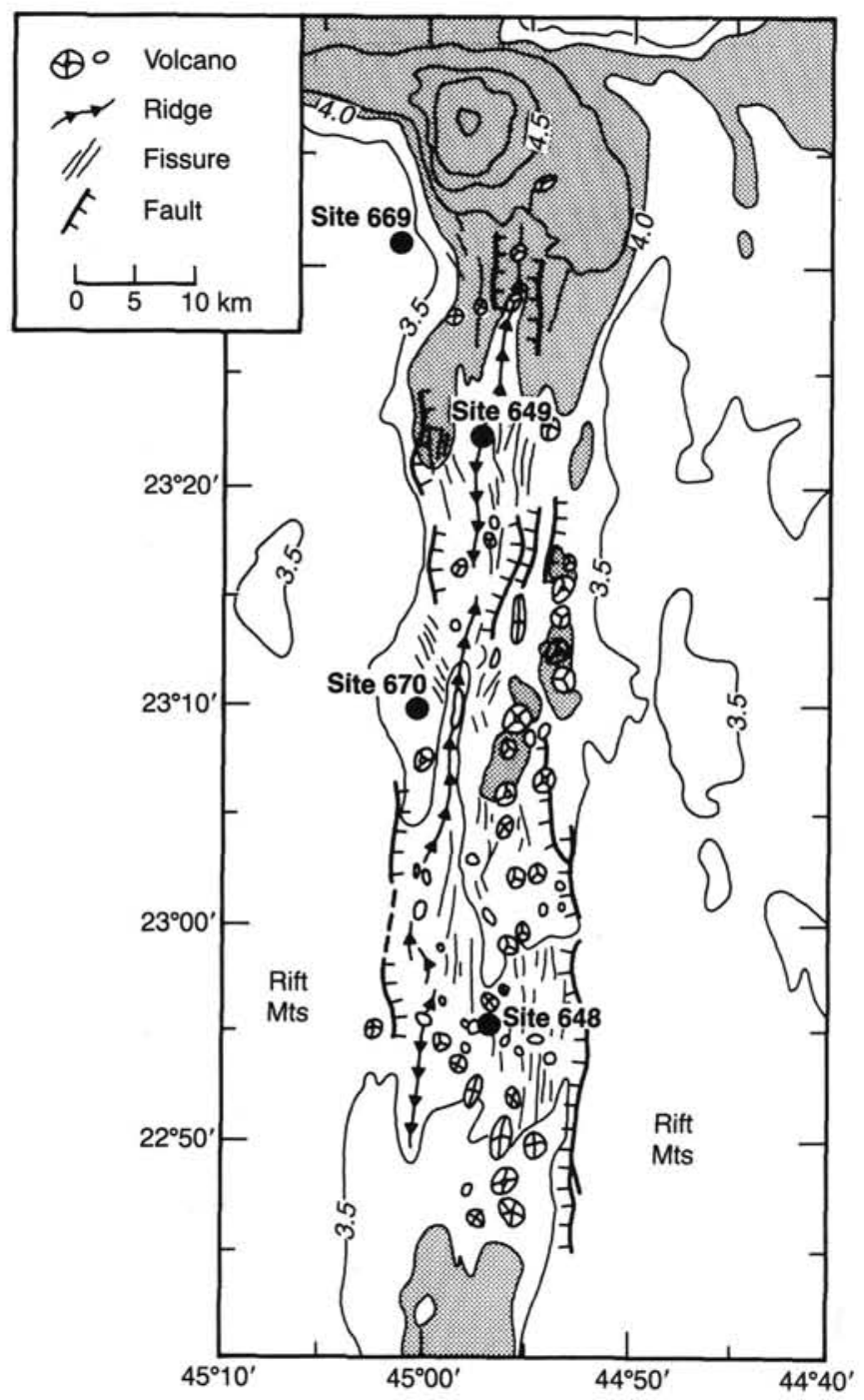

Figure 4. Simplified tectonic map of the inner rift valley of the MARK area based on the Sea Beam and SeaMARC I site-survey results. Location of ODP drilling sites shown for reference. Depths $>4 \mathrm{~km}$ are shaded.

R.10 in Fig. 6) and the geological evidence of a zone of intense fissuring and faulting within the rift valley (Karson et al., 1986) are additional evidence of the existence of a "zero-offset" transform, or spreading-cell boundary, in this area.

\section{SUMMARY}

Results from these various studies lead to a fairly consistent picture of the structure and tectonics of the MARK area. The 100 -km-long rift valley consists of at least two, possibly three, individual spreading cells. These ridge segments are each in different stages of magmatic and tectonic development and appear to operate as discrete and independent units for periods of at least a few million years.

The most recent volcanic activity in the MARK area is associated with the median ridge in the northern part of the rift valley, where the Snake Pit hydrothermal deposit was discovered and drilled on Leg 106 (ODP Site 649). This linear volcanic edifice is constructed of pillow lavas and flows and is continuous for at least $40 \mathrm{~km}$ along strike. An older, magmatically inactive and extensively fissured rift valley segment occurs in the south- ern part of the MARK area. This ridge segment extends across the regional topographic high $70 \mathrm{~km}$ south of the Kane transform and includes Serocki Volcano (ODP Site 648). An anomalous region about $20 \mathrm{~km}$ wide separates the volcanically active northern rift valley from the older, inactive spreading cell to the south. This zone, which is associated with a major seismic discontinuity, may be a "zero-offset" transform that has been magma starved during the evolution of the two adjacent segments. ODP Site 670 is in this anomalous zone, on the lower west wall of the median valley, where an extensive outcrop of serpentinized peridotite was discovered during the ALVIN field program.

Drilling in the MARK area on Legs 106 and 109 thus sampled several of the important tectonic provinces within this surprisingly complex segment of the Mid-Atlantic Ridge. This drilling, coupled with the results of other recent geological and geophysical investigations in the MARK area, provide important new constraints on the temporal and spatial variation of accretionary processes at slow-spreading ridges.

\section{ACKNOWLEDGMENTS}

This work was supported by a contract (67-84) from the Joint Oceanographic Institutions, Inc., to the University of Rhode Island with subcontracts to Lamont-Doherty Geological Observatory, Dalhousie University, and Woods Hole Oceanographic Institution. We especially wish to thank the officers and crew of the Robert C. Conrad and the Hudson and the Sea Beam and SeaMARC I technicians for the skill and professionalism with which the site survey was performed.

\section{REFERENCES}

Bryan, W. B., Thompson, G., and Ludden, J. N., 1981. Compositional variation in normal MORB from $22^{\circ}-25^{\circ} \mathrm{N}$ : Mid-Atlantic Ridge and Kane Fracture Zone. J. Geophys. Res., 86:11815-11836.

Cormier, M. H., Detrick, R. S., and Purdy, G. M., 1984. Anomalously thin crust in oceanic fracture zones: new seismic constraints from the Kane Fracture Zone. J. Geophys. Res., 89:10249-10266.

Detrick, R. S., and Purdy, G. M., 1980. Crustal structure of the Kane Fracture Zone from seismic refraction studies. J. Geophys. Res., 83: 3759-3777.

Detrick, R. S., Fox, P. J., Kastens, K., Ryan, W.B.F., and Karson, J., 1984. A Sea Beam survey of the Kane Fracture Zone and the adjacent Mid-Atlantic Ridge rift valley. Eos, 65:1106.

Detrick, R. S., Ryan, W.B.F., Mayer, L., Fox, P. J., Kong, L., Manchester, K., Kastens, K., Karson, J., and Pockalny, R., 1985. Mid-Atlantic Ridge/Kane Fracture Zone Final Site Survey Report. Prepared for Joint Oceanographic Institutions Inc.

Detrick, R. S., Honnorez, J., and Leg 106 Scientific Party, 1986. Drilling the Snake Pit hydrothermal sulfide deposit on the Mid-Atlantic Ridge, lat. $23^{\circ} 22^{\prime}$ N. Geology, 14:1004-1007.

Fox, P. J., 1972. The geology of some Atlantic fracture zones, Caribbean escarpments and the nature of the oceanic basement and crust [Ph.D. dissert.] Columbia University, New York.

Fox, P. J., and Gallo, D., in press. The geology of North Atlantic transform plate boundaries and their aseismic extensions. In Tucholke, B. E., and Voyt, P. (Eds.), The Geology of North America: The Western North Atlantic Region: Geol. Soc. Am., DNAG Series.

Francheteau, J., and Ballard, R. D., 1983. The East Pacific Rise near $21^{\circ} \mathrm{N}, 13^{\circ} \mathrm{N}$ and $20^{\circ} \mathrm{S}$ : interferences for along-strike variability of axial processes at mid-ocean ridges. Earth Planet. Sci. Lett., 64:93116.

Karson, J. A., and Dick, H.B.J., 1983. Tectonics of ridge-transform intersections at the Kane Fracture Zone. Mar. Geophys. Res., 6:51-98.

Karson, J. A., Brown, J. R., and Winters, A. T., 1986. Seafloor spreading in the MARK area. Eos, 67:1213.

Karson, J. A., Thompson, G., Humphris, S., Edmond, J., Bryan, W., Winters, A., Brown, J., Pockalny, R., Casey, J., Campbell, A., Klinkhammer, G., Palmer, M., Kinzler, R., and Sulanowska, M., in press. Along-axis variations in seafloor spreading in the MARK area, $\mathrm{Na}$ ture.

Kong, L., Ryan, W.B.F., Mayer, L., Detrick, R., Fox, P. J., and Manchester, K., 1985. Bare-rock drill sites, ODP Legs 106 and 109: evidence for hydrothermal activity at $23^{\circ} \mathrm{N}$ in the Mid-Atlantic Ridge. Eos, 66:936. 


\section{R. S. DETRICK ET AL.}

Louden, K. E., and Forsyth, D., 1982. Crustal structure and isostatic compensation near the Kane Fracture Zone from topography and gravity measurements-I spectral analysis approach. Geophys. J. $R$. Astron. Soc., 68:725-750.

Mayer, L. A., Ryan, W.B.F., Detrick, R., Fox, P. J., Kong, L., and Manchester, K., 1985. Structure and tectonics of the Mid-Atlantic Ridge south of the Kane Fracture Zone based on SeaMARC I and Sea Beam site surveys. Eos, 66:1092.

Miyashiro, A., Shido, F., and Ewing, M., 1969. Composition and origin of serpentinites from the Mid-Atlantic Ridge, $24^{\circ}$ and $30^{\circ} \mathrm{N}$. Contrib. Mineral. Petrol., 32:38-52.

Miyashiro, A., Shido, F., and Ewing, M., 1970. Petrologic models for the Mid-Atlantic Ridge. Deep-Sea Res., 17:109-123.

Pockalny, R. A., Detrick, R. S., and Fox, P. J., in press. The morphology and tectonics of the Kane transform from Sea Beam bathymetry data. J. Geophys. Res.
Purdy, G. M., and Detrick, R. S., 1986. Crustal structure of the MidAtlantic Ridge at $23^{\circ} \mathrm{N}$ from seismic refraction studies. J. Geophys. Res., 91:3734-3762.

Purdy, G. M., Rabinowitz, P. D., and Schouten, H., 1979. The Mid-Atlantic Ridge at $23^{\circ} \mathrm{N}$ : Bathymetry and magnetics. In Melson, W. G., Rabinowitz, P. D., et al., Init. Repts. DSDP, 45: Washington (U.S. Govt. Printing Office), 119-128.

Schouten, H., and White, R. S., 1980. Zero-offset transforms, Geology, 8:175-179.

Schulz, N. J., Detrick, R. S., and Miller, S. P., 1986. Three-dimensional inversion of magnetic anomalies in the Mid-Atlantic Ridge rift valley south of the Kane Fracture Zone. Eos, 67:1213.

Sleep, N. H., and Biehler, S., 1970. Topography and tectonics at the intersections of fracture zones and central rifts. J. Geophys. Res., 75: 2748-2752.

van Andel, T. H., Phillips, J. D., and Von Herzen, R. P., 1969. Rifting origin for the Vema fracture zone in the North Atlantic. Earth Planet. Sci. Lett., 5:296-300.

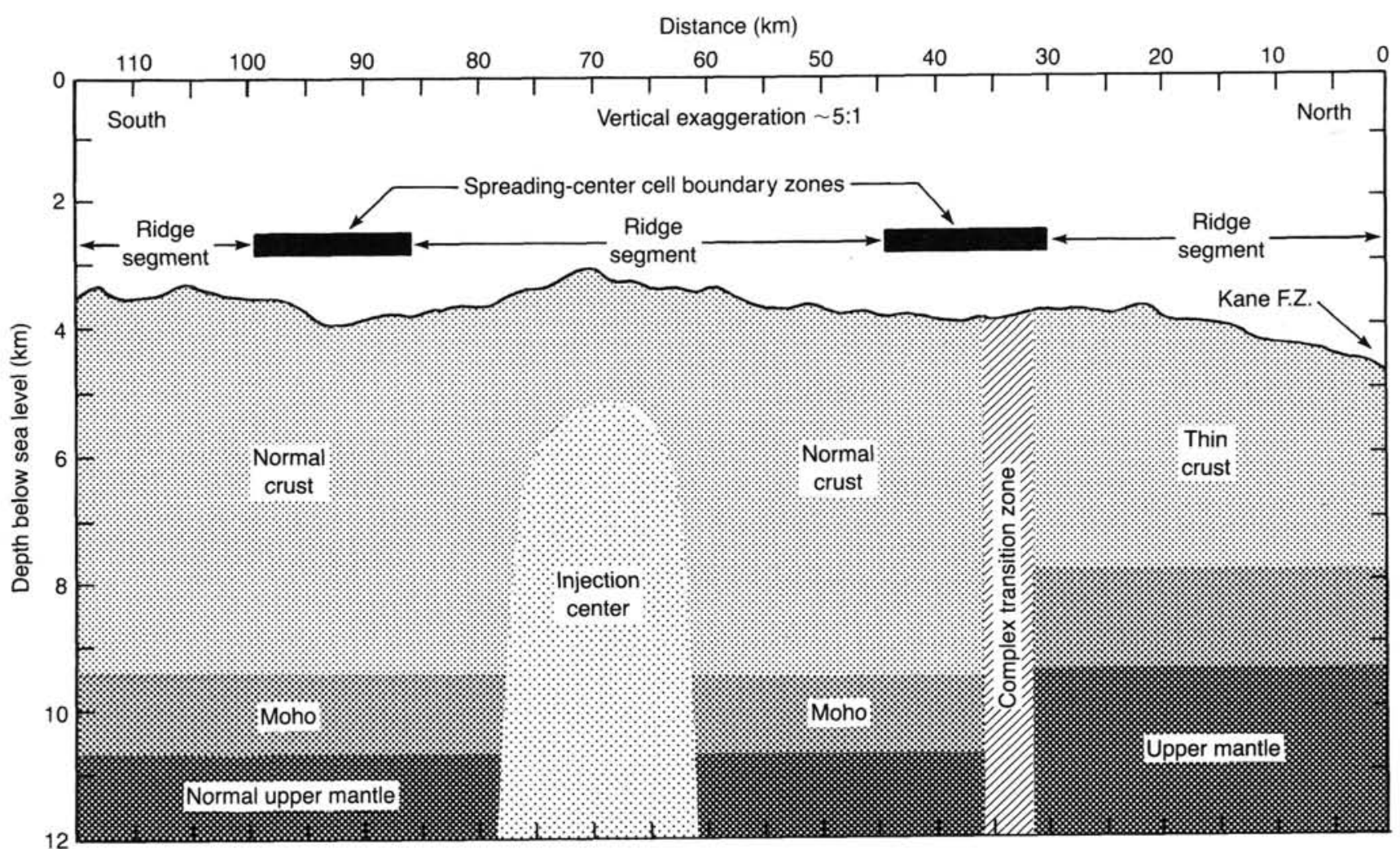

Figure 5. Crustal structure along the rift valley in the MARK area, on the basis of a recent seismic-refraction study (from Purdy and Detrick, 1986). 

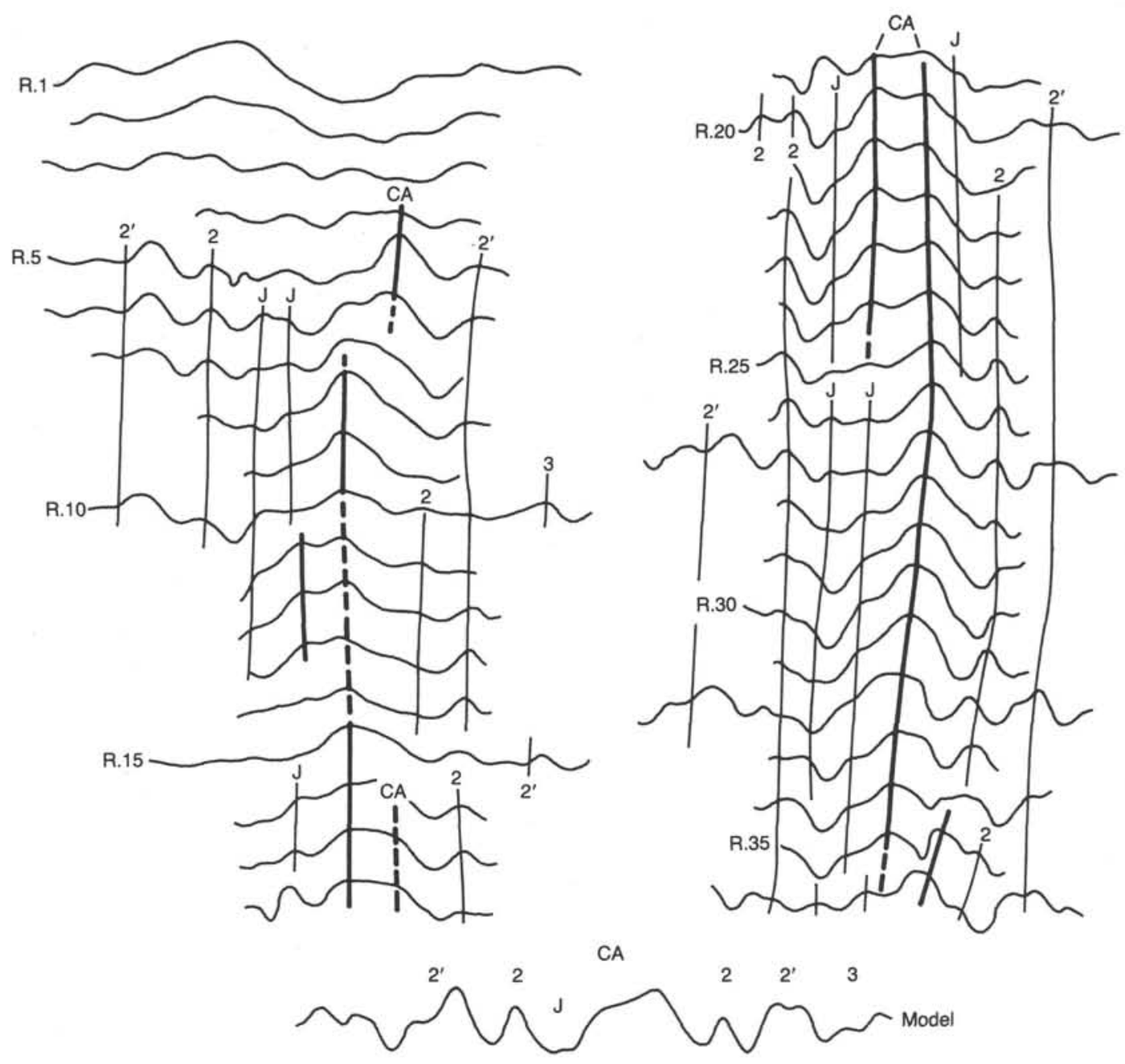

\section{IIIII $\square$ पा Iम IIIII

$$
1.41-\mid-1.13
$$

Half rate $(\mathrm{cm} / \mathrm{yr})$

Figure 6. Magnetic-anomaly profiles across the MARK rift valley. The profiles are arranged from north (top left) to south (bottom right). Anomaly identifications are based on the model profile shown in the figure, which was calculated assuming asymmetric spreading at $1.41 \mathrm{~cm} \mathrm{yr}^{-1}$ to the west and $1.13 \mathrm{~cm} \mathrm{yr}^{-1}$ to the east (from Schulz et al., 1986). Note the changing shape of the central magnetic anomaly along the rift valley. 


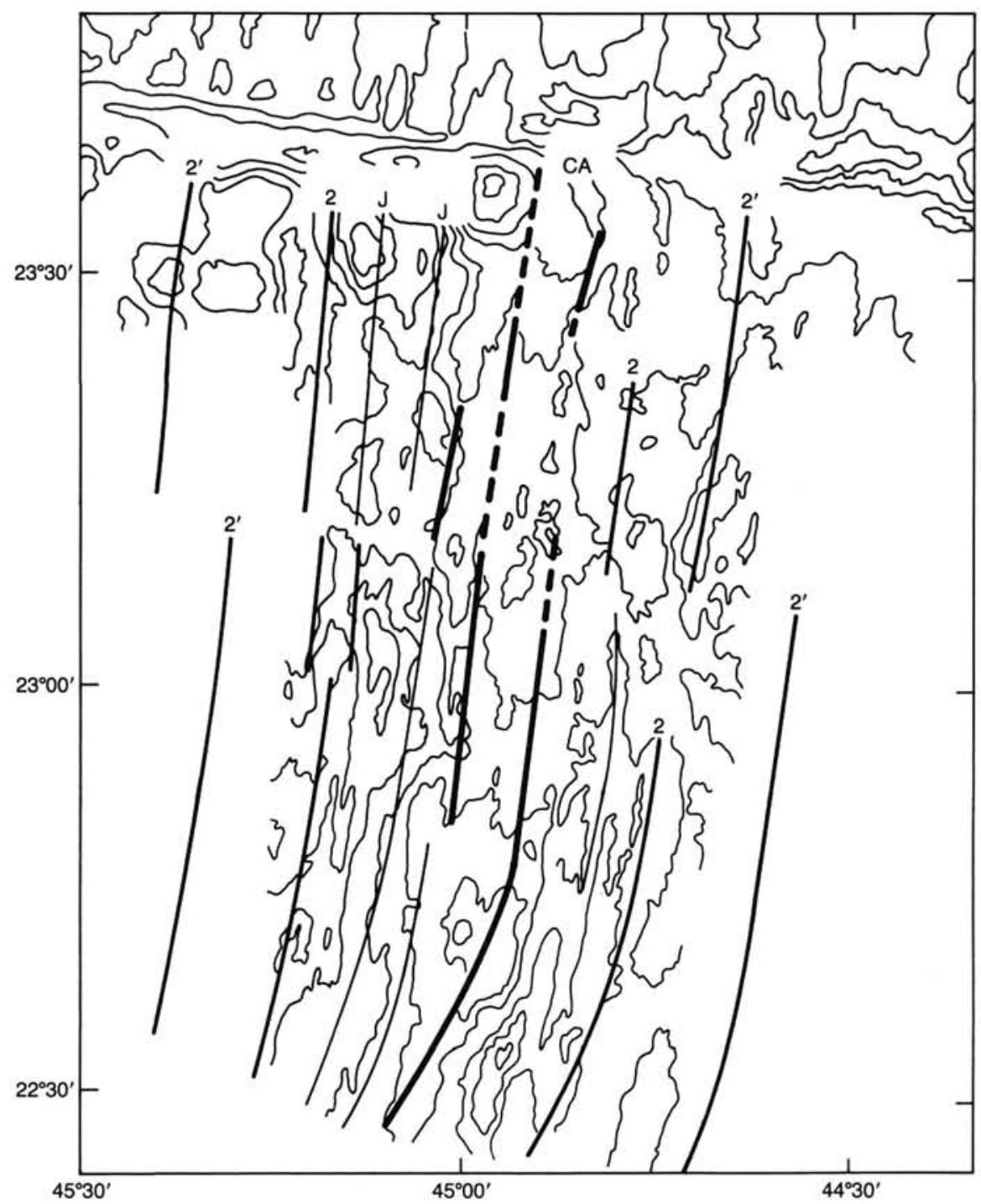

Figure 7. Magnetic-anomaly identifications in the MARK area based on data collected during the Sea Beam survey. The duplication of the Jaramillo Event $(J)$ and anomaly 2 on the western ridge flank indicate at least two small eastward jumps of the axis of accretion. Before the most recent ridge jump occurred, a small transform fault existed $50 \mathrm{~km}$ south of the Kane Fracture Zone. $\mathrm{CA}=$ central anomaly. 